\title{
A vulnerabilidade como condição antropológica segundo o motivo "Escada da vida" em uma xilogravura do século 19
}

\author{
Vulnerability as an anthropological condition according to the motif "Ladder of \\ Life" in a woodcut from the 19th century
}

\author{
Helmut Renders* \\ Elizabete Cristina Costa-Renders ${ }^{* *}$
}

\begin{abstract}
Resumo
Este artigo se dedica ao aparecimento do tema da vulnerabilidade, a partir do século 18 , em xilogravuras cuja narrativa visual se refere ao processo de envelhecimento das pessoas em analogia com o motivo da escada ou dos degraus da vida. A ausência da consideração da deficiência como um possível atravessamento do ciclo da vida disparou o problema investigativo: Como se dá o aparecimento do tema da vulnerabilidade em xilogravuras cuja narrativa visual se refere ao motivo da escada ou dos degraus da vida, acompanhada por uma narrativa religiosa? Apresenta os resultados de uma pesquisa documental exploratória, realizada nos acervos do Museu da Imagem na cidade de Epinal, França, do Museu das Culturas, na cidade de Basileia, Suíça e da Igreja Estadual de Estugarda, Alemanha, no mês de julho de 2017. Argumenta, como primeiro resultado, comparando as narrativas visuais educacionais e religiosas, que há uma modificação da narrativa visual do motivo da escada da vida e que seu aparecimento antecipa, na área da educação, mas não na área da teologia, a consideração do respeito à vulnerabilidade como condição antropológica. Como segundo resultado, mostra-se a importância da cultura visual como narrativa própria e fonte essencial para as ciências humanas, em especial, para educação e as ciências da religião, neste caso a ressignificação da vulnerabilidade humana no campo da educação inclusiva que exige um novo olhar para a condição humana.
\end{abstract}

Palavras-chave: Cultura visual. A xilogravura "O ser humano nas diferentes idades / O julgamento universal”. Vulnerabilidade. Educação Inclusiva. Ciências da Religião.

\begin{abstract}
This article focuses on the appearance of the theme of vulnerability, from the 18th century, on woodcuts whose visual narrative refers to the process of people's aging in analogy with the motif staircase or steps of life. The emergence of the consideration of disability as a possible crossing of the life cycle has triggered the investigative problem: How does the issue of vulnerability arise in woodcuts whose visual narrative refers to the motif for the staircase or steps of life, accompanied by a religious narrative? It presents the results of an exploratory documentary research, realized in the archives of the Museum of the Image in the city of Epinal, France, of the Museum of Cultures, in the city of Basel, Switzerland and of the State Church in Stuttgart, Germany, in July 2017. It argues as a first result, comparing the educational and religious visual narratives, that there is a modification of the visual narrative of the reason for the ladder of life and that its appearance anticipates, in the field of education, but not in the field of theology, the consideration of respect for vulnerability as an anthropological condition. As a second result, is shown the importance of visual culture as a proper narrative and an essential source for the human sciences, especially for the fields of education and religious studies, which in this case giving evidence for the beginning of a new perspective about the human condition.
\end{abstract}

Keywords: Visual Culture. The woodcut "The human being in different ages / The universal judgment". Vulnerability. Inclusive Education. Religious Studies.

\footnotetext{
Artigo submetido em 2 de outubro de 2019 e aprovado em 20 abril de 2020.

* Doutor em Ciências da Religião pela UMESP. Professor da UMESP. País de origem: Alemanha. E-mail: helmut.renders@metodista.br

*** Doutora em Educação pela Unicamp. Professora da UMESP e da Universidade Municipal de São Caetano do Sul. País de origem: Brasil. E-mail: elizabetecostarenders@gmail.com
} 


\section{Introdução}

Este artigo dedica-se à interpretação de xilogravura L'homme dans les différents âges / Jugement universel du genre humain ${ }^{1}$ editado por Pierre-Vincent e Philbert Roîné em Nantes, entre 1823 e 1826, em busca da sua perspectiva referente à vulnerabilidade humana. Como método propusemos a pesquisa documental exploratória, baseada em xilogravuras e litografias dos séculos 16 ao 18 encontradas nos acervos do Museu da Imagem, na cidade de Epinal, França, do Museu das Culturas, na cidade de Basileia, Suíça e da Igreja Estadual de Estugarda, Alemanha. Na primeira secção “O motivo 'Estações da vida' ...” interpretamos o desenvolvimento do motivo e estabelecemos um fundamento do nosso argumento fundamental. Em " $A$ narrativa dupla do motivo articula..." argumentamos que a interpretação interdisciplinar corresponde ao tecido fundamental da xilogravura estudada e sua composição temática dupla. As duas próximas seções introduzem aos nossos argumentos centrais. Na secção "Aproximações da educação inclusiva...” afirmamos, baseados principalmente na observação das modificações do motivo entre 1550 e 1750, que houve um aparecimento do discurso da vulnerabilidade "antes do tempo". Já na secção O tema da vulnerabilidade humana e a xilogravura "Estações da vida": uma perspectiva das ciências da religião mostrará que, diferente da narrativa educacional, a narrativa religiosa ainda não reflete o tema da vulnerabilidade, nem divina, nem humana.

\section{0 motivo "Estações da vida" na cultura visual europeia: origens e modi- ficações no século 18}

Narrativas sobre o motivo "Estações da vida", "Degraus da vida” ou "As diferentes idades" são antigas e aparecem já na Antiguidade. Entre os filósofos há os casos do poeta Sólon (aproximadamente 600 a.C.) que contava dez estágios com sete anos cada. Hipócrates (cerca de 450 a.C.) referiu-se a sete estágios e Aristóteles ${ }^{2}$ (aproximadamente 350 a.C.) distinguia as idades da juventude, a vida primordial ou a maturidade e velhice. Os estudos focam normalmente em idades especiais (HABER, 1998; MINOIS, 1989), mas há alguns estudos transversais como os de J. A. Burrow (1986, p. 5) que diferenciam entre “... a teoria dos biólogos de três, a teoria dos fisiologistas de quatro e a teoria dos astrólogos de sete idades" e Ehmers (2008, col. 80)

\footnotetext{
${ }^{1} \mathrm{O}$ ser humano nas diferentes idades / O julgamento universal do gênero humano. Daqui em diante: “O ser humano... / O julgamento...".

${ }^{2}$ Retomaremos Aristóteles mais adiante ao considerarmos a vulnerabilidade aproximada à questão da deficiência.
} 
que lembra também a analogia entre a vida e o "... ciclo do dia (a infância como aurora e a velhice como noite da vida) ...”. Quanto às leituras religiosas cristãs dos primeiros quatro séculos em relação às diferentes idades, Christian Gnilka (1972) destaca, na sua obra Aetas spiritualis - Idades espirituais, o tema da superação das limitações de cada idade e apresenta, entre outros, “...o puer senex, a criança que atua como um sábio de idade, baseado [na narrativa] do menino Jesus no templo...” (apud METZLER, 2013, p. 255).3

$\mathrm{Na}$ arte cristã do Ocidente, a partir do século 13, aparece o motivo de uma escada ou de um ciclo da vida com fases de ascensão e declínio, primeiro, em iluminuras, ou seja, nas pinturas à mão em livros, ainda, não impressos. Um exemplo famoso é o livro dos salmos de Robert Lisle, criado ao redor de 1310 na Inglaterra (figura 1).

Figura 1: LISLE, Robert. "A roda das dez idades do ser humano". In: Livro dos Salmos. [Londres?]: [cerca 1310]

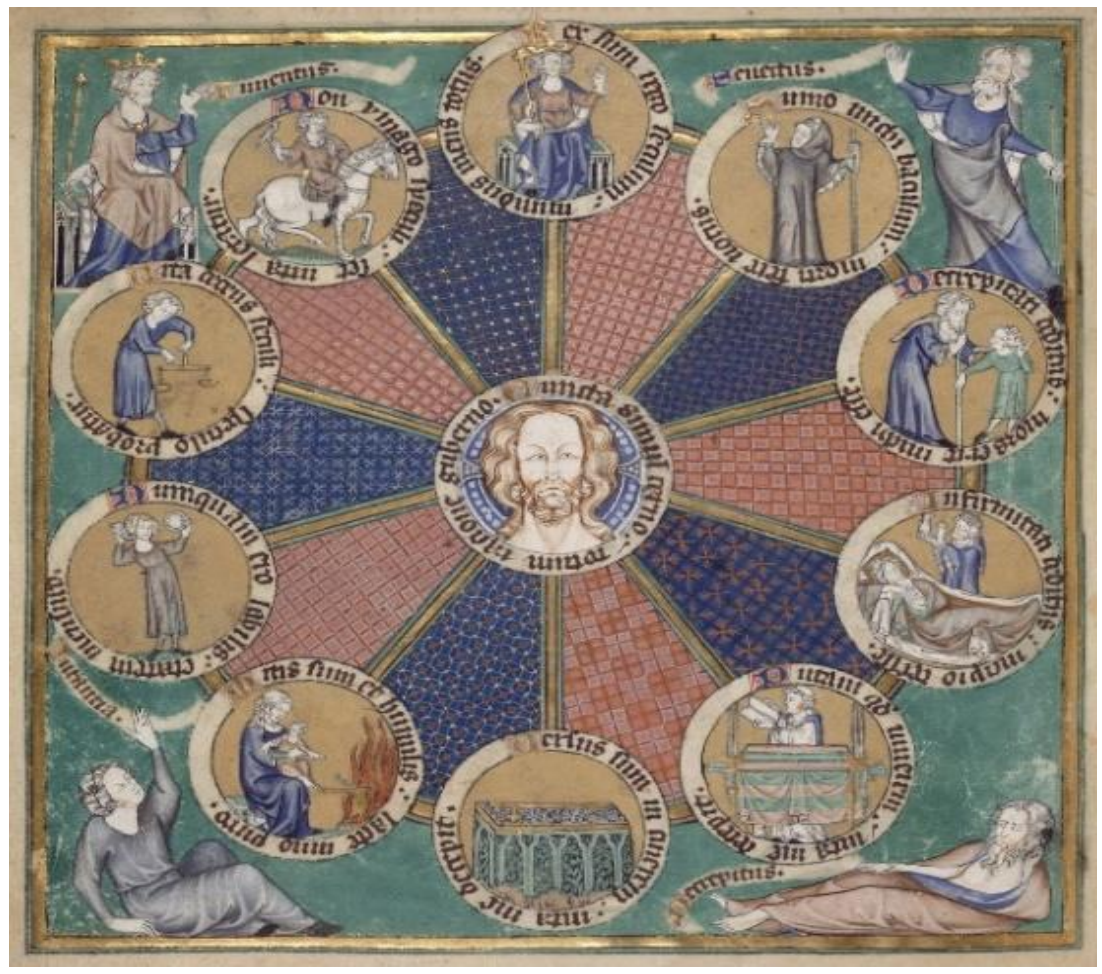

Fonte: British Library Images Online

O centro dessa pintura é ocupado por uma cabeça masculina com cabelos e barba loira, atributos iconográficos de Jesus Cristo. Ao redor, lê-se, iniciado pela letra

\footnotetext{
${ }^{3}$ A narrativa visual mais correspondente a esse imaginário é uma escada sem declínio (inglês "Iadder", alemão "Leiter"). Uma antiga inspiração representa a narrativa da escada de Jacó (Gênesis 28,11-19). O motivo reaparece no século 6 no tratado bizantino Scala or Climax Paradisi [A escada da Divina Ascensão] do monge João Clímaco, dividido em 30 etapas. Um famoso retrato disso é o ícone "A Escada da Ascensão Divina" do século XII no Mosteiro de Santa Catarina, no Monte Sinai, Egito. A partir do século 8, houve ícones que transpuseram o tema para visualizar a narrativa do triplo caminho dos místicos (esvaziamento, iluminação e união mística), retratando pessoas subindo uma escada entre a terra e o céu. Retornamos a este assunto mais para frente, quando o motivo retorna na época da modernidade.
} 
grega alfa dourada: "Unita simul reino: totum ratione guberno" [Manter o reino unido: toda a razão de governar]. Desse centro irradiam dez raios como uma roda, e cada um termina em medalhões circulares que ilustram as dez épocas do ser humano, mais especificamente, as fases da vida de um rei. A fase do crescimento ou da ascensão até a maturidade é dividida em cinco etapas (infância, pré-adolescência, adolescência, juventude e maturidade), e a do declínio é ilustrada por uma pessoa idosa com um cajado, com uma criança e com um médico. Já as duas últimas imagens se referem ao seu funeral e ao túmulo. Nos quatro cantos da pintura, encontram-se ainda quatro homens que, em conjunto, formam uma roda. Pelas suas idades distintas, da direita abaixo à esquerda abaixo, aumenta a idade; deve tratar-se de uma segunda referência ao motivo da roda da vida ou da vida em quatro estações, um nome sagrado ao mundo pré-cristão. 4 A partir daí aparece o motivo com certa frequência, porém, ainda em diferentes formas de organização visual.

O padrão visual do tema da escada da vida com dez degraus estabeleceu-se com o alemão e luterano Jörg Breu5 (figura 2) em 1540 e com o holandês e reformado Cornelis Anthonisz ${ }^{6}$, em 1550. Além do motivo da escada da vida e do juízo final, a obra de Breu contém, ainda, o motivo da dança da morte com os vivos, simbolizada pelo esqueleto na parte central acima, atirando a sua flecha. Nessa xilogravura, o motivo da roda da vida já deu lugar ao motivo da escada. Mantém-se a divisão em dez etapas, considerando nove com retratos humanos, por sua vez, acompanhados por nove animais alegóricos e, como décima estação, um sarcófago. Abaixo da escada, no centro, encontra-se Cristo, porém, agora como juiz. Damos destaque à um detalhe que acompanha os 10 degraus das idades, animais simbólicos abaixo de cada par. No caso das duplas das pessoas nos degraus decentes, esses animais ridicularizam a idade a qual eles pertencem: o raposo representa falsidade; o lobo, violência; o cachorro chupando um osso, a incapacidade de se manter, e o burro, a perda das faculdades racionais. 7

\footnotetext{
${ }^{4}$ Desde a antiguidade com ampla influência até a modernidade, o número quatro era um elemento organizador de muitos aspectos da vida: as quatro estações do ano, os quatro elementos básicos, os quatro modos da alma ou tipos humanos, as quatro direções (geografia), as quatro operações básicas de cálculo (matemática), as quatro virtudes cardeais e, na época das conquistas e antes da descoberta da Austrália, os quatro continentes.

${ }^{5}$ Pintor; viveu entre 1510 e 1547 em Augsburgo.

${ }^{6}$ Viveu entre 1505 e 1553 em Amsterdã.

${ }^{7}$ Segundo Anja Schöne (1996, p. 843-844), “[...] a equiparação alegórica entre (até dez) períodos [da vida] humana e animais é disseminada por escrito e iconograficamente. Evidências iniciais podem ser encontradas no Midrash Kohelet, em que um burro, um cachorro e um macaco representam o homem como marido, pai e ancião, bem como em comentários dos livros Eclesiastes e Gênesis. A primeira fonte em língua alemã encontra-se em um livro de canções de Augsburg (1471) de Klara Hätzlerin: "10 anos um cordeiro, 20 anos um bezerro, 30 anos um touro, 40 anos um leão, 50 anos uma raposa, 60 anos um lobo, 70 anos um gato, 80 anos um cão, 90 anos um burro e 100 anos um ganso. Desde o fim do século 15, as diferentes idades são também representadas como escada de idades (Lebenstreppe, o/a autor/a)
} 
Figura 2: BREU, Jörg. Lebensalter des Mannes, cerca 1540

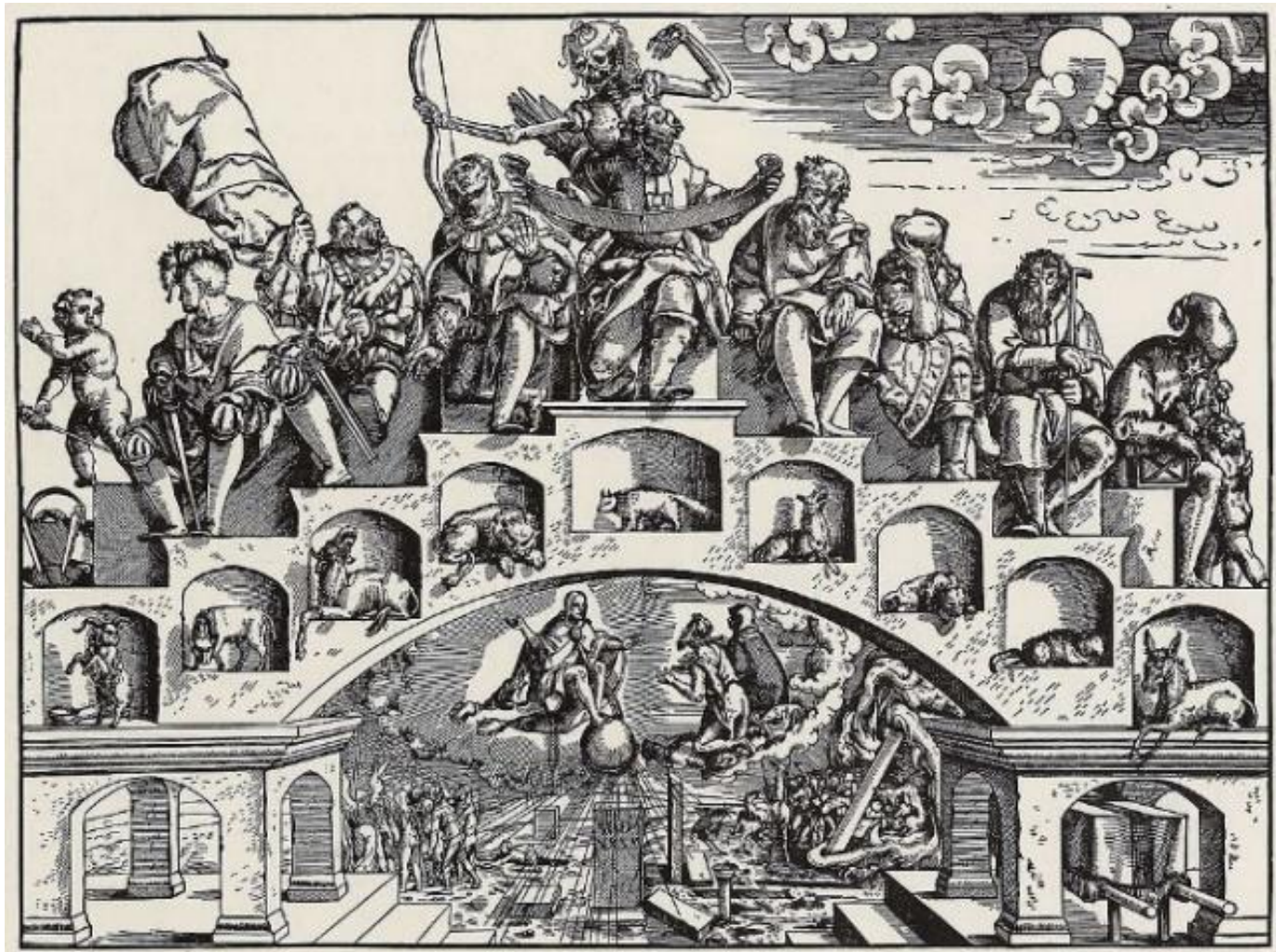

Fonte: https://commons.wikimedia.org

Cornelis Anthonisz, de 1550, mantém todos estes elementos, organizados de forma independente, acrescendo algumas passagens textuais explicativas e eles se repetem também, em sua grande maioria, na xilogravura por nós investigada, $O$ ser humano... / O julgamento criado em Nantes entre 1823 e 1826 (figura 3), 8 e, de fato, se trata de um fenômeno europeu:

A escada da vida é uma das poucas imagens - no sentido literal e figurativo da vida e da velhice na história europeia, cuja popularidade está bem documentada tanto nas classes média como baixa. As grandes manufaturas e os grandes fabricantes de imagens dos séculos 18 e 19 espalharam esse motivo em inúmeras variantes e em enormes tiragens em todo o mundo ocidental (EHMER, 2008, p. 683).

Figura 3: Roîné, Pierre-Vincent e Philbert (eds.). O ser humano... / O julgamento... Nantes [entre 1823 e 1826]

na qual os animais são posicionados abaixo de nove estados. Este tipo de representação é mais encontrado até o século 17". A relação entre esta canção e a obra de Jörg Breu é evidente, e o importante é que os animais relacionados com a idade criticam e ridicularizam comportamentos na velhice.

${ }^{8}$ Estas informações são contidas na própria xilogravura: "Chez ROINÉ père et fils, fabricants de Cartes à jouer et de Dominoterie, pont d'Erdre à Nantes" [Em ROINÉ pai e filho, fabricantes de cartas de jogo e Dominoterie, Pont d'Erdre em Nantes]. Outra informação importante é que a imagem passou pela censura do estado francês: "Déposé à La Préfecture de la Loire-Inférieure". 


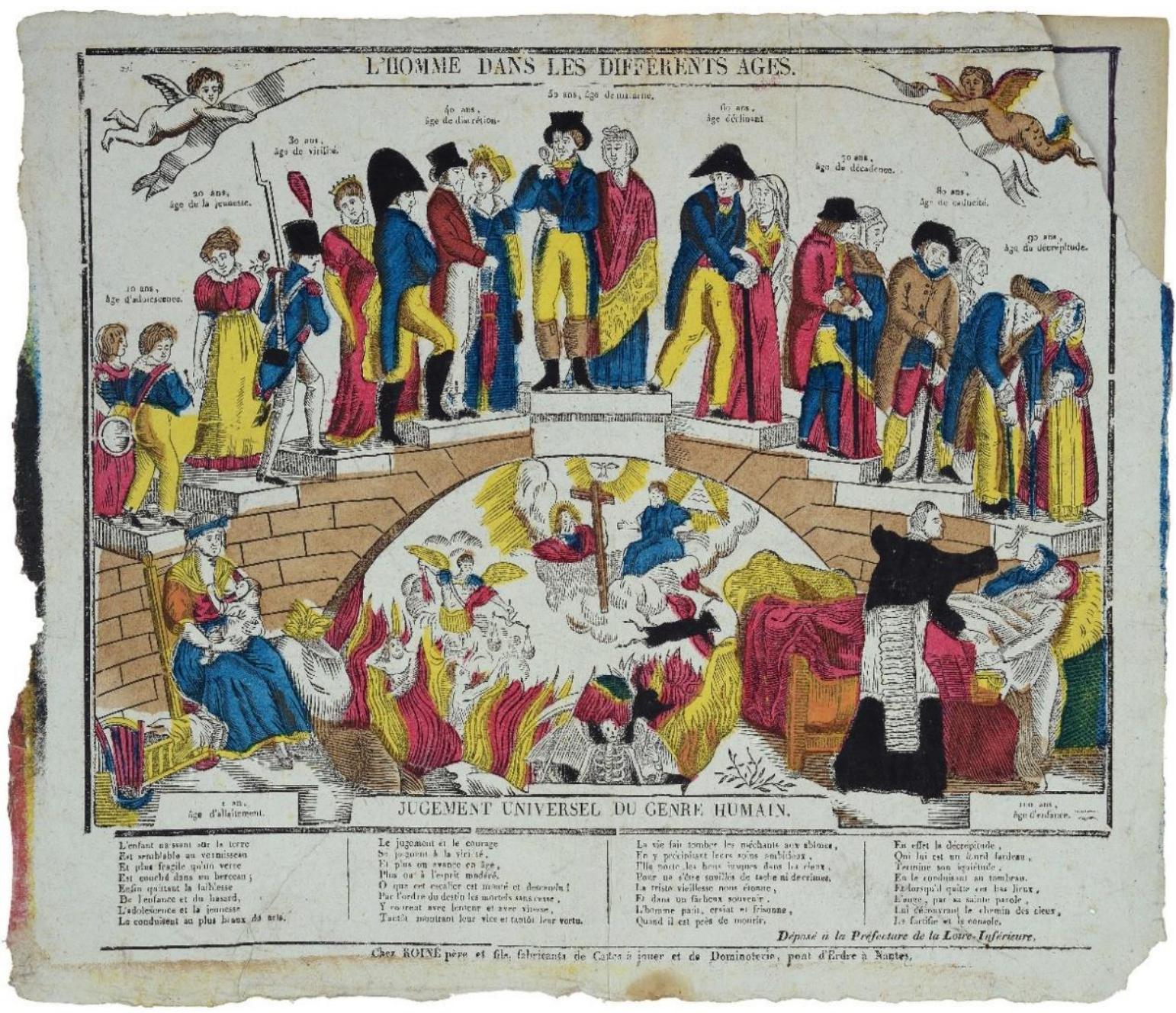

Fonte: Musée de I’Image Ville d’Épinal número de acervo 2010.5.6841 B, negativo fotográfico de H. Rouyer.

Em nosso caso, a xilogravura de Nantes ${ }^{9}$ dirige-se a classes mais populares, mas com duas modificações: desaparecem os animais alegóricos e com isso seu significado subjacente da ridicularização da idade avançada; segundo, aparece o motivo da cama tanto no início da vida (muitas vezes, mostrando um neném ou um casal de nenês juntos no berço) como ao fim da vida (novamente, mostrando um casal na cama). Essas duas modificações atingem a grande maioria dos motivos depois de 1750 e que se repetem independentes das narrativas religiosas.

\section{A narrativa dupla do motivo articula tanto aspectos educacionais como religiosos}

\footnotetext{
${ }^{9}$ Mencionamos aqui somente que a xilogravura francesa ainda mantém a estrutura essencial de um emblema com seus três elementos básicos da inscricptio [título ou lema], pictura [imagem, no caso uma imagem composta por duas narrativas visuais distintas] e subscriptio [texto explicativo, em geral com rimo; no caso, que relaciona as duas narrativas ao seu final].
} 
A composição da xilogravura editada pelos irmãos Philbert divide-se em duas grandes cenas: a descrição de pessoas em 11 fases distintas e uma cena do purgatório e julgamento final. Quanto às pessoas na escada, a narrativa visual descreve práticas típicas relacionadas com certas idades (como mamar, brincar, casar, precisar cada vez mais de ajuda etc.) sem mencionar a religião:

\begin{abstract}
Uma escada da vida é caracterizada por uma organização estritamente bidimensional de figuras que representam fases de vida. Na horizontal, a sequência das figuras demonstra a idade crescente, na vertical explicita uma hierarquia dos degraus de idade. Quanto mais alto o degrau, maior era a apreciação, a força ou o poder (THIISSEN; OVERDICK, 2013, p. 51).
\end{abstract}

Assim, também afirma Mary Dove (1986, p. 3): "a tendência medieval era exaltar e glorificar a meia-idade que, sob uma variedade de nomes de idade, era representada como sendo possuída por exuberância, força e maturidade. Um dos seus nomes era idade perfeita [...]”. Em outras palavras, a ideia principal da organização da escada da vida era tradicional, hierárquica e focava no tema do envelhecimento.

Esta xilogravura, como um todo, contém elementos religiosos: na parte superior, um anjo e um demônio e, na parte inferior, um padre. Abaixo da escada, encontram-se referências à trindade, o símbolo da cruz, um anjo, demônios e pessoas entre chamas. Assim, o enredo dessa xilogravura é composto por duas narrativas. Uma primeira narrativa educativa que é observadora e uma segunda narrativa religiosa, a qual situa a perspectiva educativa numa narrativa religiosa.

Figura 4: Roîné, Pierre-Vincent e Philbert. O ser humano... / O julgamento... Nantes [entre 1823 e 1826]. Detalhe: os dois títulos da xilografia

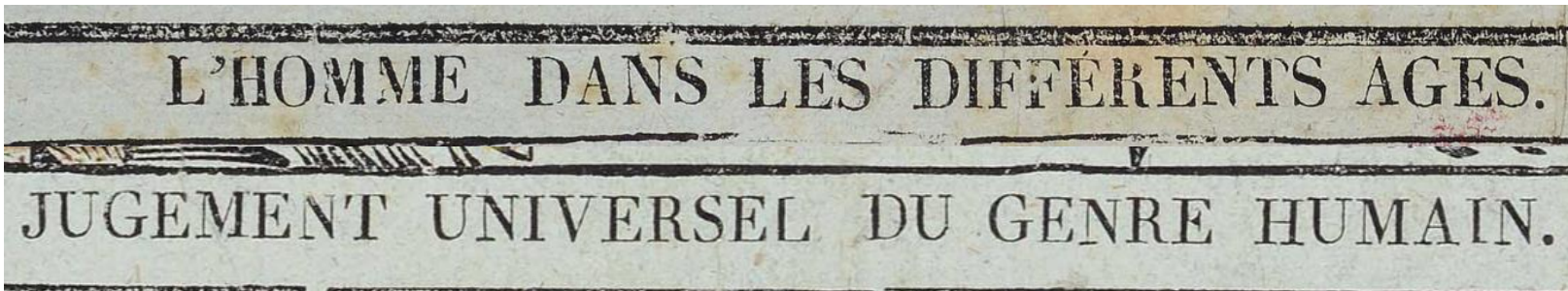

\title{
Fonte: Musée de I'ImageVille d'Épinal número de acervo 2010.5.6841 B, negativo foto- gráfico de H. Rouyer.
}

Consequentemente, há também dois títulos: "O ser humano nas diferentes idades" na parte superior e “O julgamento universal do gênero humano” na parte in- 
ferior (figura 4). ${ }^{10}$ Por isso, discutimos, a seguir, a presença do tema vulnerabilidade, tanto na perspectiva da educação inclusiva como das ciências da religião. Especialmente, a partir da categoria de deficiência e as múltiplas mentalidades a ela vinculadas que, no decorrer da história humana, desconsiderou a vulnerabilidade ${ }^{11}$ como condição antropológica e divina.

\section{A evidência do surgimento do tema da vulnerabilidade no enredo edu- cacional da xilogravura: aproximações a partir da perspectiva da educa- ção inclusiva}

Já dizemos que a introdução do símbolo da cama ocorreu aos poucos ${ }^{12}$ e aparece plenamente a partir de $1750^{13}$. Analisamos, em seguida, essa inclusão e a parte descendente da escada, com seus supostos significados dentro da perspectiva do paradigma da inclusão.

Figura 5: Roîné, Roîné, PierreVincent e Philbert. O ser humano... / O julgamento... Nantes [entre 1823 e 1826] Detalhe: uma mulher amamentado um neném e um berço.

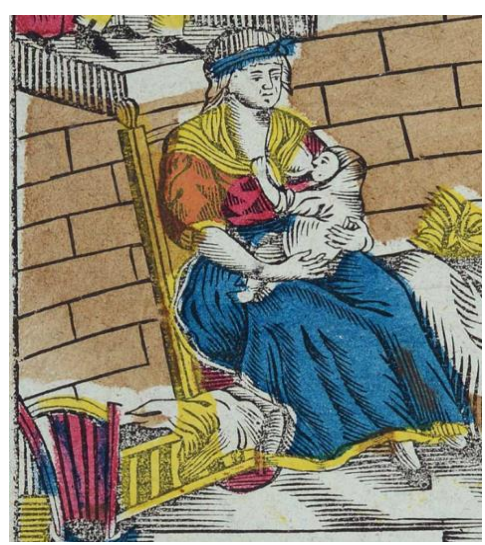

Fonte: Musée de I'Image Ville d'Épinal número de acervo 2010.5.6841 B, negativo fotográfico de H. Rouyer.
Figura 6: Roîné, Pierre-Vincent e Philbert. O ser humano... / O julgamento... Nantes [entre $1823 \mathrm{e}$ 1826] Detalhe: um casal de idosos deitados numa cama.

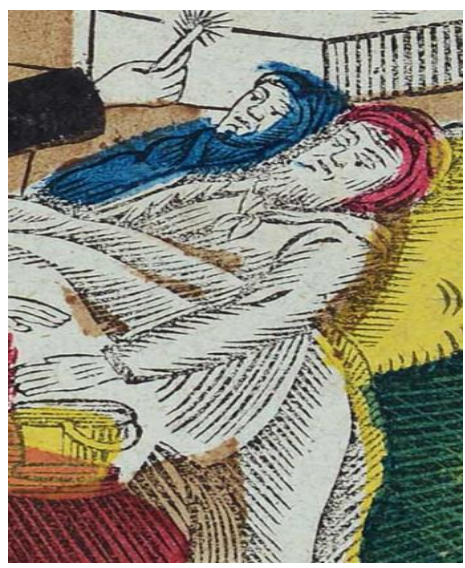

Fonte: Musée de I'Image Ville

d'Épinal número de acervo 2010.5.6841 B, negativo fotográfico de H. Rouyer.

O tema da vulnerabilidade humana é destacado no início e no fim do ciclo, nas cenas do ser humano como neném e como idoso (figuras 5 e 6), ambos representados

\footnotetext{
${ }^{10}$ Outra xilogravura de 1760 do acervo do Musée de I'Image Ville d'Épinal, o número 2010.5.6842 B, apresenta também os dois títulos, porém em ordem inversa, primeiro Le jugement, depois Le cours de la vie de l'homme ou I'h[o]mme dans ses [ou les?] diferentes ages. A mesma titulação dupla encontra-se na xilogravura de 1830 do Musée de l'Image Ville d'Épinal número de acervo 2010-5-6844.

${ }^{11} \mathrm{O}$ conceito de vulnerabilidade nos remete a duas perspectivas diferentes, a condição humana (espécie humana é vulnerável) e a construção social (a sociedade constrói e impõe situações de maior vulnerabilidade a determinados grupos). Neste artigo, nos detemos a pergunta pela dignidade na condição humana de vulnerabilidade.

${ }^{12} \mathrm{Na}$ obra de John Bunton (1701, p. 11) aparece no primeiro emblema, dedicado à infância e à adolescência, um neném em seu berço. Não há, ainda, uma correspondência a respeito da idade na velhice.

${ }^{13}$ Exemplos são S.N. Le cours de la vie de l'homme ou l'homme dans ses différents âges. Lyon: Louis-Martin-Roch Joubert / Paris: Veuve Daudet, [entre 1764 e 1773] acervo do Musée de l'Ímage Ville d'Épinal, número de acervo 2010.5.6842 A; PITTS, J. The various ages and degrees of human, 1811.
} 
como pessoas incapazes de andar e, por esse motivo, são relacionados com a cama. Trata-se de um ciclo que vai da infância, 1 an, âge d'allaitement [ 1 ano, idade da amamentação] à velhice, considerada uma segunda infância: 100 ans, âge d'enfance [100 anos, idade da infância]. Na etapa final da vida, volta-se para um aspecto em comum com a fase do início da vida: a fase de poucas condições funcionais e de alta vulnerabilidade.

A parte descendente da escada apresenta quatro representações de um casal: "60 anos, idade em declínio"; "70 anos, idade de decadência”; "80 anos, idade da demência”; "90 anos, idade da invalidez” (figura 7).

\section{Figura 7: Roîné, Pierre-Vincent e Philbert. O ser humano... / O julgamento... Nantes [entre 1823 e 1826] Detalhe: o lado da descida da escada da vida}

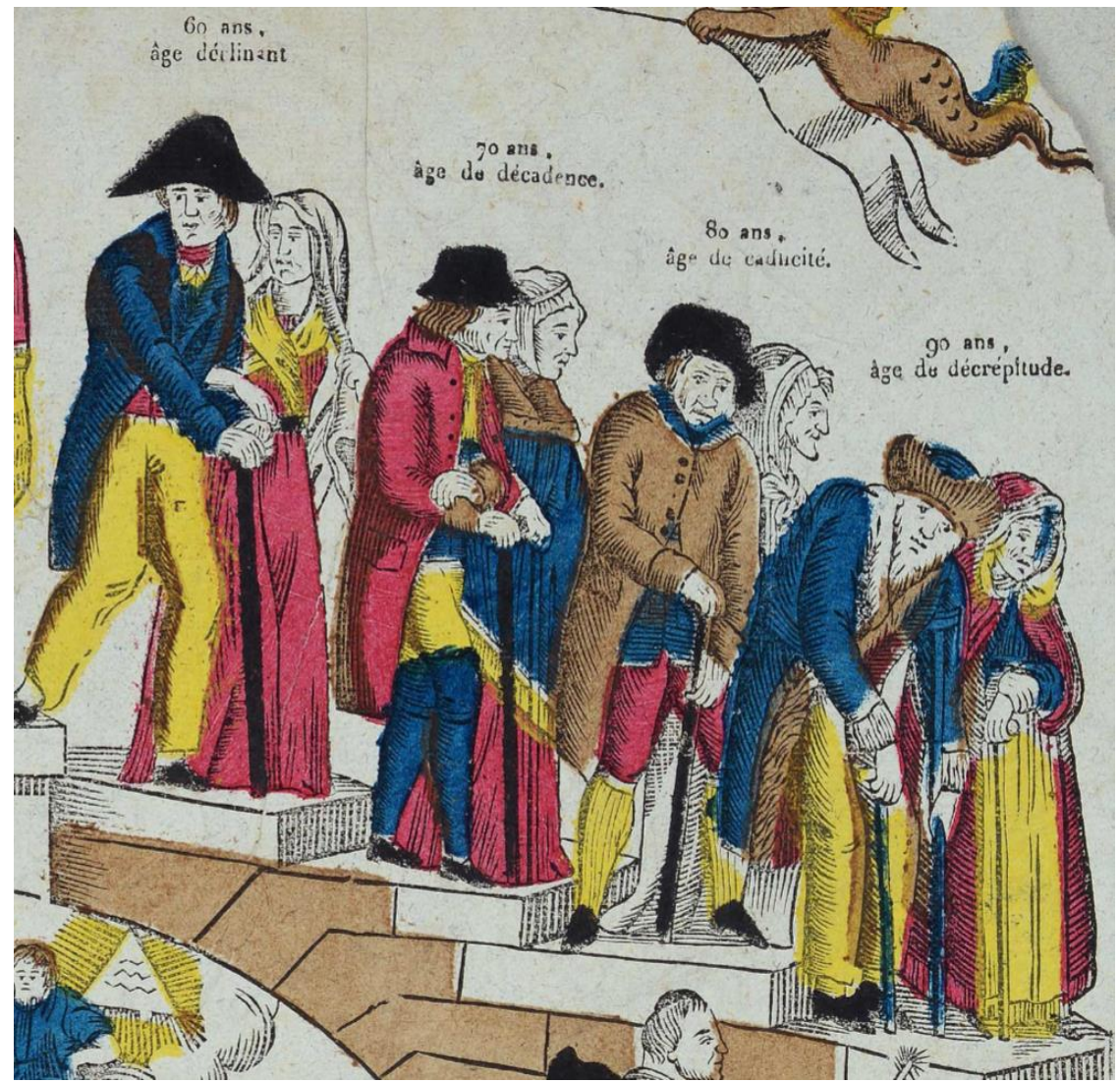

Fonte: Musée de I'Image Ville d'Épinal número de acervo 2010.5.6841 B, negativo fotográfico de H. Rouyer.

Georges Minois (1989, p. vii), por um lado, afirma que o motivo da feiura ou decrepitude da velhice tem sua origem na Antiguidade e corresponde à apreciação 
dos ideais estéticos e antropológicos greco-romanos na Renascença. ${ }^{14}$ Se seguirmos essa linha de raciocínio, a xilogravura não se abrirá para uma representação de vulnerabilidade. Por outro lado, David G. Troyansky (1998, p. 98) observa que "[...] obras sobre o século 18 descrevem uma mudança da ridicularização ao respeito [...] uma mudança de imagem nos dois lados do rio Reno [...]” das pessoas com idade avançada.

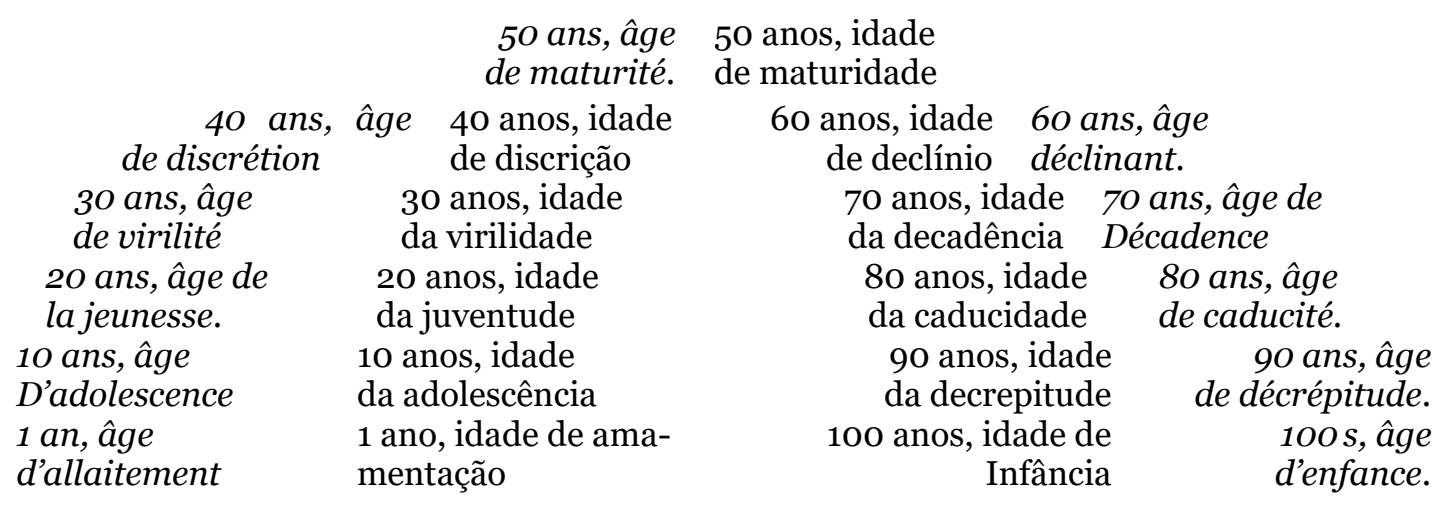

As categorias aqui usadas ${ }^{15}$ indicam que o abandono da ridicularização, ainda, não instalou o respeito: ainda falta qualquer sentimento de alegria ou realização quanto à idade, mas, destaca-se pela percepção da triste contingência da vulnerabilidade humana na infância e na velhice. ${ }^{16}$

Percebe-se que, em comparação às obras anteriores, a inclusão das cenas de um e de cem anos de idade, avança na questão da sinalização da vulnerabilidade como parte da condição humana de forma significativa. Mesmo que isso não supere totalmente a ambiguidade da representação, principalmente por manter sua proximidade visual com as representações das obras do século 16, a xilogravura de Nantes apresenta um processo de transição na visão da idade, iniciado na segunda parte do século 18. Este processo, conforme veremos na próxima seção, parece não ser consi-

\footnotetext{
${ }^{14}$ Uma outra intencionalidade no retrato de pessoas idosas como feias ou da sua "decrepitude" é mencionada por Ronald Raminelli. Ele chama a atenção como nos retratos de indígenas brasileiros como canibais a iconografia de mulheres indígenas idosas se distingue dos retratos das outras idades pela sua feiura. "Se a misoginia cristã explica a ligação da imagem feminina à perversidade, a teoria de degeneração permite entender as características atribuídas às velhas índias. [...] O apetite sexual e o estranho gosto de ingerir carne humana não são antagônicos, mas, complementares; constituem características inseparáveis das mulheres enrugadas e de seios caídos. [...] As velhas índias, portanto, encarnaram esse estado avançado da decrepitude, ressaltado em seu pendor para os prazeres da carne. Os desvios da sexualidade e o gosto pelo repasto canibal constituem indícios inegáveis da degeneração. Os homens, por sua vez, foram poupados pelos missionários e viajantes e não eram vistos dessa mesma forma" (RAMINELLI, 2011, p. 43). A iconografia de livros sobre Brasil, em sua grande parte de viajantes, seguiu neste ponto os ensinamentos religiosos do século 16 e 17 . Apesar de ser altamente relevante no contexto cultural brasileiro, esta leitura não parece significativa para a nossa gravura, primeiro, por representar em 10 dos 11 degraus um casal; segundo, por não se referir a povos da periferia do império, mas, uma classe considerada importante; terceiro, pela falta de indícios nas narrativas textuais.

${ }^{15}$ Descrições do potencial humano [30, 40 e 50 anos]; descrições das limitações humanas [60, 70, 80 e 90 anos]; descrições técnicas [10 e 20 anos] e descrições da vulnerabilidade máxima [1 e 100 anos].

${ }^{16}$ Assim lê-se na poesia abaixo, na segunda estrofe: "La triste vieillesse nous étonne, / Et dans um fâcheux souvenir" [A velhice triste nos espanta, / Em uma triste memória].
} 
derado nas mentalidades sobre a deficiência no decorrer dos séculos, mas aponta para a possibilidade da força na vulnerabilidade. Essa interpretação se sustenta na análise do texto explicativo que vem abaixo da imagem. ${ }^{17}$ A saber,

1. O julgamento e a coragem,

Se unem à virilidade

E quanto mais se avança na idade,

Mais se tem o espírito moderado.

Oh, como esta escada subiu e desceu!

Pela ordem do destino os mortais sem cessar,

Correm nela com lentidão e velocidade,

Algumas vezes mostram seu vício,

algumas vezes, sua virtude.

2. A vida faz os bandidos caírem no abismo,

Precipitando nele seus ambiciosos cuidados,

Ela leva os bons aos céus,

Para não se sujarem

nem com manchas nem com crimes.

A triste velhice nos espanta,

Em uma triste memória.

O homem aposta, tem medo e tem arrepios

Quando está próximo da morte.

3. De fato, a decrepitude

Que é um fardo pesado para ele,

Acaba com seu tormento,

Conduzindo-o ao túmulo,

E quando ele deixa estes lugares ignóbeis,

$\mathrm{O}$ anjo, por sua santa palavra,

Descobrindo-lhe o caminho dos céus,

Fortalece-o e o consola.

Nessa subscriptio, as pessoas idosas são descritas como moderadas, cujo estado pode causar tristeza. Além das reflexões genéricas sobre a fragilidade e vulnerabilidade da vida, aparece um elemento de consolo, um elemento religioso: "O anjo, por sua santa palavra, / Descobrindo-lhe o caminho dos céus, / Fortalece-o e o consola”.

Entendemos que a não ridicularização da vulnerabilidade humana e a não hierarquização das diferentes fases da vida, por um lado, carregam uma percepção antropológica que vem ao encontro do paradigma da inclusão no século 21. Todavia, a xilogravura, ainda, desconsidera a vulnerabilidade como condição antropológica em todo o ciclo da vida, foca somente nas suas pontas (primeira infância e velhice).

\footnotetext{
17 "Le jugement et le courage / Se jognent à la virilité, / Et plus on avance en âge, / Plus on à l'esprit modéré. // Oh, que cet escalier est monté et descendu! / Par l'ordre du destin les mortels sans cesse, / Y courent avec lenteur et avec vitesse, /Tantôt montrant leur vice et tantôt leur vertu. / // La vie fait tomber les méchants aux abîmes, / En y précipiant leurs soins ambitieux, / Elle porte les bons jusques dans les cieux, / Pour ne s'être souillés de tache ni de crimes.// La triste vieillesse nous étonne, // Et dans un fâcheux souvenir. / L'homme parit, craint et frissonne, / Quando il est près de mourir./ En effet la décrépitude, / Qni lui est un lourd fardeau, / Termine son inquiétude, / En le conduisant au tombeau. / Et lorsqu'il quitte ces bas lieux, / L'ange, par sa sainte parole, / Lui découvrant le chemin des cieux, / Le fortifie et le console" [Tradução: Ivna Maia Fuchigami].
} 
Se é possível localizar as narrativas sobre o motivo "Estações da vida”, "Degraus da vida" ou "As diferentes idades", com redução da vulnerabilidade à primeira infância e velhice, desde os tempos gregos, a não aceitação da deficiência também remonta aos tempos da Antiguidade. Na Roma Antiga, as crianças que nasciam com deficiência eram abandonadas em cestos nas margens do rio. Aristóteles, no contexto da Grécia Antiga, sinaliza que “[...] com respeito a conhecer quais os filhos que devem ser abandonados ou educados, precisa existir uma lei que proíba nutrir toda criança deforme” (ARISTÓTELES, 1966, p. 150). Já para Platão, “a natureza humana tem uma vinculação com o divino, com os deuses, cuja natureza é de perfeição e de bondade" (OLIVEIRA, 2004, p.134). Os fortes e perfeitos pertenceriam ao "gênero do ouro". Aos que não atendiam à natureza perfeita (os corporalmente defeituosos, os fracos etc.), restaria a condenação à morte. Na Antiguidade, entendia-se que a pessoa com deficiência traria em si a manifestação do castigo divino. Lucius Sêneca (4-65 d.C) testemunha que, ainda na era cristã, aconteciam afogamentos de crianças com deficiência - “[...] nós sufocamos os pequenos monstros; nós afogamos até mesmo as crianças quando nascem defeituosas e anormais: não é a cólera e sim a razão que nos convida a separar os elementos sãos dos indivíduos nocivos" (AMARAL, 1995, p. 46). Portanto, na Antiguidade há uma total desconsideração da deficiência como parte do ciclo da vida em suas estações, degraus ou diferentes idades. O que se testemunha é o entendimento mítico da deficiência, sendo esta definida como resultado de castigo divino e marca do pecado humano. Tal entendimento levou à aversão às pessoas com deficiência e, evidentemente, à desconsideração da vulnerabilidade como condição antropológica. Na Idade Média, no entanto, superase a legitimação religiosa do sacrifício ou eliminação das pessoas com deficiência, mas permanece a rejeição a sua presença no convívio social. Isto resultou na visão caritativa, com o advento das instituições religiosas que acolhem e cuidam destes rejeitados. Ou seja, continua-se escondendo as pessoas que nos lembram sobre a vulnerabilidade humana no decorrer do ciclo da vida. Essa percepção social sobre a deficiência não mudou até a Idade Moderna, quando o tema ganhou as nuances do antropocentrismo.

Com o advento das ciências, na Idade Moderna, a mentalidade míticocaritativa foi substituída pelo visão clínico-terapêutica, permanecendo, contudo, a 
visão excludente e segregacionista ${ }^{18}$. O próprio "Iluminismo, com a visão legitimadora da ciência, defendeu a higienização social e isolou a 'anormalidade' com a finalidade de reabilitar ou curar" (SÁ, 2002, p. 52).

As mentalidades excludentes em relação às deficiências são cíclicas, nunca desapareceram. Mas desde a Modernidade até as duas últimas décadas do século 20, tem predominado a desconsideração da vulnerabilidade como contingência em todas as fases da vida humana, o que pode ser acompanhando nas, literalmente, inumeráveis imagens representando o ciclo da vida publicadas posterior à xilogravura por nós aqui apresentada. ${ }^{19}$ Prevaleceu o pensamento eugênico - ou a visão clínico-terapêutica - que aplica "as leis biológicas ao aperfeiçoamento da espécie humana" (OLIVEIRA, 2004, p. 149), construindo a muralha da higienização no sentido da tentativa de eliminação das deficiências. Ou seja, raramente temos considerado a vulnerabilidade do ser humano como parte essencial desse "homo complexus" (MORIN, 2003, p. 140).

Nessa contemporaneidade, tem-se buscado substituir o modelo médico de deficiência (baseado no o conceito de incapacidade) pelo modelo social de deficiência. Modelo este ancorado no paradigma da inclusão, onde entende-se a incapacidade "como resultante da relação entre as pessoas (com e sem deficiência) e o meio ambiente”. A partir daqui, a incapacidade não se reduzia mais à limitação fisiológica, morfológica ou funcional. Diferentemente, foi entendida como resultado dos impedimentos ou barreiras socialmente construídas.

Segundo os teóricos do modelo social, a perspectiva positivista característica do modelo médico acabou atribuindo um sentido negativo às diferenças fisiológicas, morfológicas e/ou funcionais, em razão de uma normatividade conceitualmente estabelecida que considerava essas diferenças como doenças/anormalidades. (BISOL, 2017, p. 93).

Assim, o paradigma da inclusão substituiu os modelos anteriores, vindo ao encontro do modelo social de deficiência, propondo o compromisso coletivo com a ga-

\footnotetext{
${ }^{18}$ No caso das pessoas com deficiência mental, CECCIM constata que "ao final do século XVIII, as pessoas com DM são denominadas de cretinos, idiotas ou imbecis, trazendo a marca do irreversível, incurável e inapelável. Troca-se de danação divina à condenação médica" (SKLIAR, 1997, p. 32).

${ }^{19}$ Você pode acessar algumas em: https://www.flickr.com/photos/rehan99/8590312900/player/11ebc8d2bf .
} 
rantia da acessibilidade e da mobilidade na sociedade. Para isso, releu-se a vulnerabilidade na dimensão social e denunciaram-se as condições de vulnerabilidade social impostas às minorias, especialmente, às pessoas com deficiência, em todas as fases da vida. Considera-se, portanto, necessário superar as "políticas compensatórias paliativas” e reconhecer a potencialidade humana em meio à vulnerabilidade sem fixá-la a determinada fase da vida.

Retomemos a palavra do anjo na xilogravura de Nantes: "Descobrindo-lhe o caminho dos céus, fortalece-o e o consola”. Esta palavra aponta para a força na vulnerabilidade. Portanto, no âmbito da discussão da vulnerabilidade como condição antropológica, consideramos a importância da educação para a condição humana desde suas limitações até a resiliência. O reconhecimento da vulnerabilidade como "condição antropológica absoluta” (STALSETT, 2019) e como mais um sinal da interdependência ${ }^{20}$ humana e cósmica - nos leva à percepção de que não somos autossuficientes e de que não temos o destino em nossas mãos (tal qual se vê nas xilogravuras estudadas). Por outro lado, a categoria vulnerabilidade também nos permite entender a deficiência não só como diferença, mas como semelhança, dificultando a estigmatização das pessoas com deficiência. Portanto, a vulnerabilidade do outro gera uma demanda ética, pois seja na primeira infância ou na velhice, todos nós carecemos do cuidado coletivamente constituído em todo o ciclo da vida. Esta percepção nos remete à essência da educação que, segundo Hanna Arendt, é a natalidade - o fato de que os seres nascem para o mundo e do seu cuidado carecem. Segundo a autora, a "educação é o ponto em que decidimos se amamos o mundo o bastante para assumirmos a responsabilidade por ele" (ARENDT, 2009, p. 247), garantindo espaço para as condições da continuidade da vida humana com dignidade.

A vulnerabilidade é um fator antropológico e ético constituinte do humano, pois a condição para o reconhecimento da vulnerabilidade do outro é a percepção de nossa própria vulnerabilidade.

\footnotetext{
20 Interdependência é um tema bastante pertinente quando pensamos na construção de uma sociedade mais humana e solidária. Vale, portanto, uma referência ao tema Hugo Assmann e Jung Mo Sung (2000).
} 
Mas a única maneira em que se pode escutar a voz, que emerge desde a vulnerabilidade, e responder a ela, é o reconhecimento da própria vulnerabilidade. Sem o reconhecimento da própria vulnerabilidade não é possível perceber a vulnerabilidade do Outro e, portanto, não é possível a ação ética. Dito de outra maneira, sem o reconhecimento da interdependência que surge de uma vulnerabilidade compartilhada, não se pode escutar e responder ao grito do sujeito (STALSETT, 2019, s/p).

Identificamos aqui uma inversão interessante: a vulnerabilidade deixa ser o lugar de exclusiva debilidade, transforma-se na força humana manifesta no coletivo. Esta força surge da vulnerabilidade compartilhada, o que também nos remete ao necessário reconhecimento da interdependência humana. Todos carecemos do cuidado um do outro e justamente essa capacidade de cuidar garantindo a dignidade de toda vida humana é a nossa força como espécie.

A consideração da interdependência humana também nos remete ao modelo pós-social de deficiência, ao discutir o papel que o corpo e sua funcionalidade. $\mathrm{O}$ "modelo pós-social contribui para repensar questões como a dor, o cuidado e a interdependência, elementos essenciais para aprofundar a inclusão" social (BISOL; PEGORINI; VALENTINI, 2017, p. 98) e também relevantes na educação para a condição humana.

A xilogravura, na sua época, com uma nova articulação visual da vulnerabilidade humana na infância e na velhice, deu os primeiros passos em direção ao surgimento de uma nova cultura de respeito ao estado da velhice. Todavia, isso não se estendeu ao ciclo da vida como todo, o que resultou na demora da consideração da vulnerabilidade como condição antropológica.

\section{A [relativa] ausência do tema da vulnerabilidade no enredo religioso da xilogravura: aproximações a partir da perspectiva das ciências da religião}

O sofrimento humano, tradicionalmente, ocupa nos discursos religiosos um lugar amplo e recebe respostas muito diferenciadas (SÖLLE, 1996). Já o tema da vulnerabilidade como uma das formas de entender o sofrimento, seja o próprio, de terceiros ou da própria divindade, é relativamente novo na narrativa cristã e aparece, literalmente, a partir do fim do século 20. 
A experiência de pessoas com uma deficiência deu um importante impulso nessa direção. Na Alemanha, especialmente o teólogo Ulrich Bach (uma pessoa com deficiência física) e Jürgen Moltmann (1987) foram os pioneiros. Eles valorizaram a aceitação da fragilidade humana como parte da condição humana (BACH, 1979, 1983, 1986), questionaram a identificação de concepções de salvação com cura (BACH, 1993) e reclamaram uma ampliação do conceito da unidade dos diferentes (BACH, 2006), incluindo as pessoas com deficiência. Com isso, foram além da compreensão de vulnerabilidade como mera fragilidade, disposta e indefesa, articulando-a ao conceito da "vulnerabilidade social". Essa nova visão acaba de ser introduzida também no Brasil: "O reconhecimento da vulnerabilidade favorece uma ética que de fato considera ou parte do outro. [...] a vulnerabilidade [é] aquilo que nos faz humanos" (ADAM, 2014, p. 353). Assim, para René Dentz e Vicente de Paula Ferreira (2017, p. 45-59) o tema da vulnerabilidade abre novos "[...] caminhos para uma teologia pósmoderna".

Quanto ao tema, ainda, mais novo de uma vulnerabilidade solidária da própria divindade (Cf. CULP, 2010; SCHOFER, 2010; GANDOLFO, 2015; BIELER, 2017), podemos mencionar, como primeiros sinais dessa linha interpretativa, as novas interpretações da cruz a partir das contribuições do teólogo alemão Albrecht Ritschl (1850, p. 83) e (1900, pp. 473-475): "A justiça de Deus [...] na sua essência é idêntica à sua graça [...]. Não é bíblico supor que qualquer um dos sacrifícios do Antigo Testamento, fundamento da analogia segundo a morte de Cristo deveria ser julgado, teria tido o significado de mover Deus da ira para a graça [...]. Não é bíblico supor que a oferta de sacrifício em si inclui um ato penal, executado não sobre o culpado, mas em cima da vítima, que toma seu lugar. A representação por sacerdote e sacramento não tem como objetivo qualquer sentido exclusivo, mas inclusivo”. Essa lógica inclusiva rompe com o paradigma sacrifical (Cf. também GIRARD, 1990) e meritocrático, abrindo o caminho para uma ênfase na compaixão que corresponde, posteriormente, a uma vulnerabilidade da própria divindade.

O que o protestante Ritschl iniciou em 1850, ainda não aparece vinte e cinco anos antes na narrativa visual e textual católica da xilogravura sob investigação. De fato, quase nada corresponde nessa narrativa visual religiosa ao tema da vulnerabili- 
dade humana ou divina. Isso poderia ter ocorrido, por exemplo, por uma ênfase na vulnerabilidade do Cristo como humano, especialmente, como crucificado e retratado em agonia. Entretanto, apesar de que a cruz, ainda, apareça nessa xilogravura, ela é vazia e segurada pelo Cristo ressurreto. Ele está assentado em uma nuvem que, por um lado, representa, na iconografia cristã, o céu e, dessa forma, por outro lado, a superação da vulnerabilidade como fragilidade.

Existe, porém, um elemento mais dialogal ou acolhedor que foge da imagem do Cristo juiz (presente, por exemplo, nas gravuras dos protestantes Jörg Breu e Cornelis Anthonisz). O Cristo ressurreto estende sua mão às pessoas que se encontram nas chamas, enfrentando o julgamento simbolizado pela balança na mão esquerda de um anjo. Mesmo que o tema da vulnerabilidade não possa ser associado à cena como um todo, talvez haja certa expressão de empatia ou benevolência atrás do gesto da mão estendida. Por um lado, não há uma articulação expressiva da vulnerabilidade divina, à qual a vulnerabilidade humana poderia corresponder. Por outro, também não há indicações de uma leitura mítica da vulnerabilidade da infância ou da velhice, trazendo explicações religiosas no sentido de um discurso punitivo da crescente vulnerabilidade na velhice. Ela é, aparentemente, considerada como algo que faz parte do ciclo da vida, sem nenhum peso religioso específico. O "julgamento universal" título da narrativa explicitamente religiosa - refere-se à soma total de cada vida ${ }^{21}$ que as pessoas entre chamas aparentemente ainda esperam: elas devem encontrar-se, então, no purgatório.

Para os vivos, o cenário religioso é descrito como um mundo dividido entre o bem e o mal, representado por um anjo e um demônio (figuras 8 e 9).

\footnotetext{
${ }^{21}$ Todas as categorias usadas nas descrições dos degraus das idades - amamentação, adolescência, juventude, virilidade, descrição, maturidade, declínio, decadência, caducidade, decrepitude e infância - não são de uma natureza especificamente religiosa ou teológica.
} 
Figura 8: Roîné, Pierre-Vincent e Philbert. $O$ ser humano... / O julgamento... Nantes [entre 1823 e 1826] Detalhe: o anjo

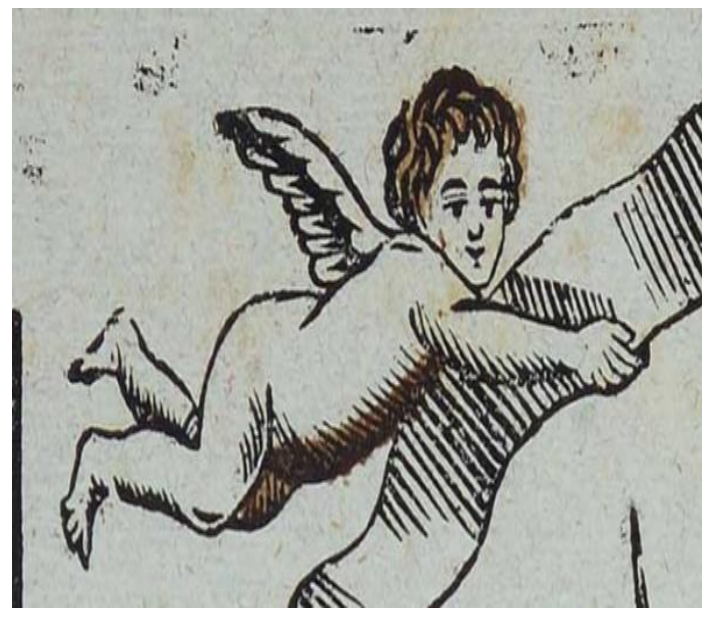

Fonte: Musée de I'Image Ville d'Épinal número de acervo 2010.5.6841 B, negativo fotográfico de H. Rouyer.
Figura 9: Roîné, Pierre-Vincent e Philbert. O ser humano... / O julgamento... Nantes [entre 1823 e 1826] Detalhe: o demônio

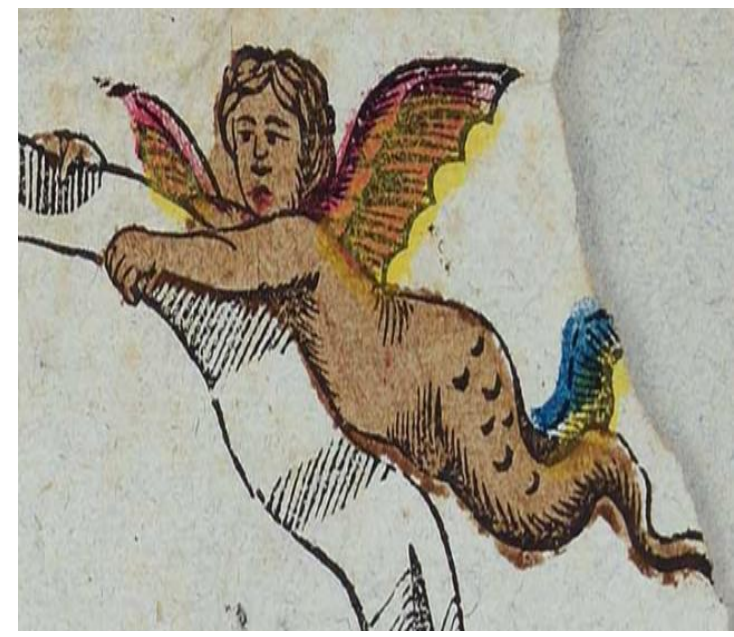

Fonte: Musée de I'Image Ville d'Épinal número de acervo 2010.5.6841 B, negativo fotográfico de H. Rouyer.

O discurso religioso, com a afirmação de um imaginário dicotômico que corresponde ao imaginário de uma luta entre o divino e o diabólico pelas almas humanas, sem nenhuma descrição de uma participação humana, é tradicional (Origines) e não deixa espaço para uma visão de uma divindade vulnerável que poderia educar o ser humano a aceitar e integrar a própria vulnerabilidade como elemento essencial de sua humanidade. A ação que responde a esta situação é uma ação sacramental, a última unção, momento representado na xilogravura. Portanto, a mão esquerda do padre ou sacerdote, mesmo que esteja em proximidade da mão esquerda do homem deitado ao lado da mulher, não a toca, não a conforta. Provavelmente, representa outra ação sacerdotal, um gesto de bênção (figura 9). A isso corresponde também sua postura corporal reta, sem nenhuma tendência de se abaixar ou ficar mais próxima, por exemplo, para escutar as vozes fracas etc. Assim, o sacerdote é retratado como autoridade religiosa em cumprimento do seu papel e atuante segundo a dramaturgia religiosa estabelecida, mas sem mostrar sinal de proximidade, empatia, compaixão ou vulnerabilidade. 


\section{Figura 10: Roîné, Pierre-Vincent e Philbert. O ser humano... / O jul- gamento... Nantes [entre $1823 \mathrm{e}$ 1826] Detalhe: o padre}

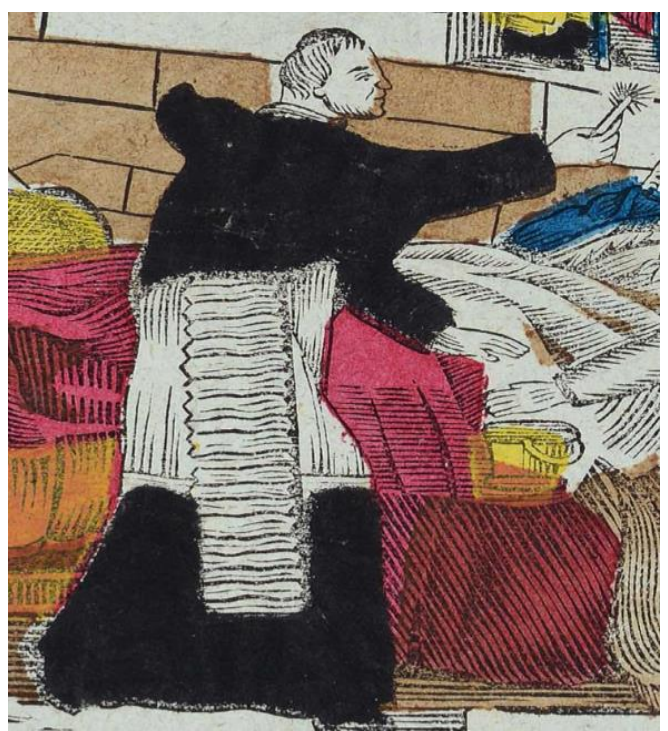

Fonte: Musée de I'Image Ville d'Épinal número de acervo 2010.5.6841 B, negativo fotográfico de H. Rouyer.

Esta noção da presença de uma visão mais tradicional da religião é, ainda, mais fortalecida pelo conjunto do tema "purgatório" (as pessoas entre chamas na parte inferior) e os motivos "Anjo com balança" (figura 11) e "Morte com ampulheta" (figura 12).

Figura 11: Roîné, Pierre-Vincent e Philbert. O ser humano... / O julgamento... [entre 1823 e 1826] Detalhe: Anjo com balança, medindo o peso das obras.

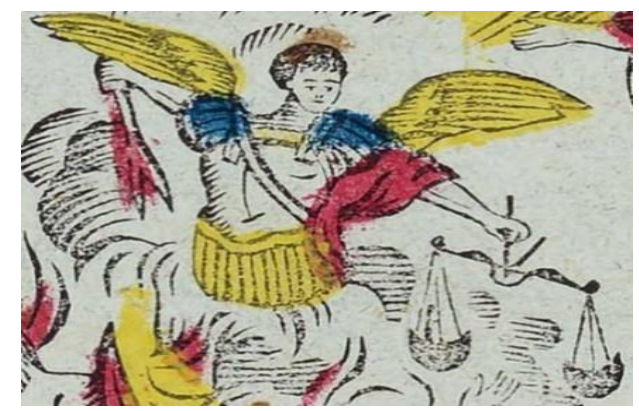

Fonte: Musée de I'Image Ville d'Épinal número de acervo 2010.5.6841 B, negativo fotográfico de H. Rouyer.
Figura 12: Roîné, Pierre-Vincent e Philbert. O ser humano... / O julgamento... Nantes [entre 1823 e 1826] Detalhe: A morte com uma ampulheta, sinalizando a finitude humana.

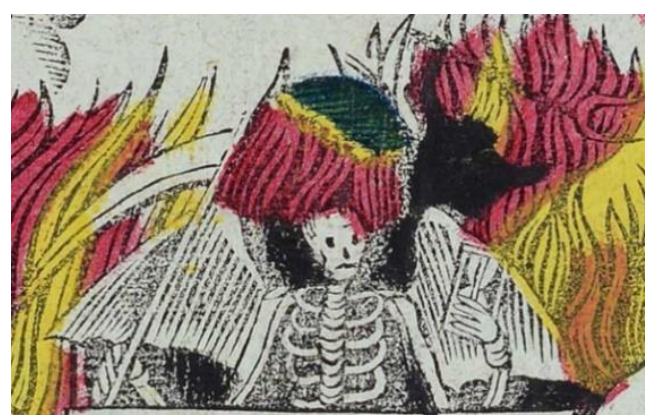

Fonte: Musée de I'Image Ville d'Épinal número de acervo 2010.5.6841 B, negativo fotográfico de H. Rouyer. 
Reparamos que o anjo segura na mão direita um tipo de lança com ponta dupla direcionada às pessoas representadas nas chamas enquanto ele observa não elas, mas a balança. O símbolo da balança refere-se à medida do peso das boas obras de cada ser humano, e a negociação da busca do equilíbrio dessa balança que passa pelo pagamento de indulgências pelos vivos, um tipo de "economia" do sagrado (MORGAN, 2015, p. 71-104), em vigor na Igreja Católica antes do Concílio Vaticano II (1962-1965 d.C.). ${ }^{22}$ Como tudo, a cena não articula nem compaixão nem vulnerabilidade divina. Trata-se de uma "justa” cobrança de fatos, dos feitos vivenciados.

Figura 12: Roîné, Pierre-Vincent e Philbert. O ser humano... / O julgamento... Nantes [entre 1823 e 1826] Detalhe: $O$ purgatório e a Trindade.

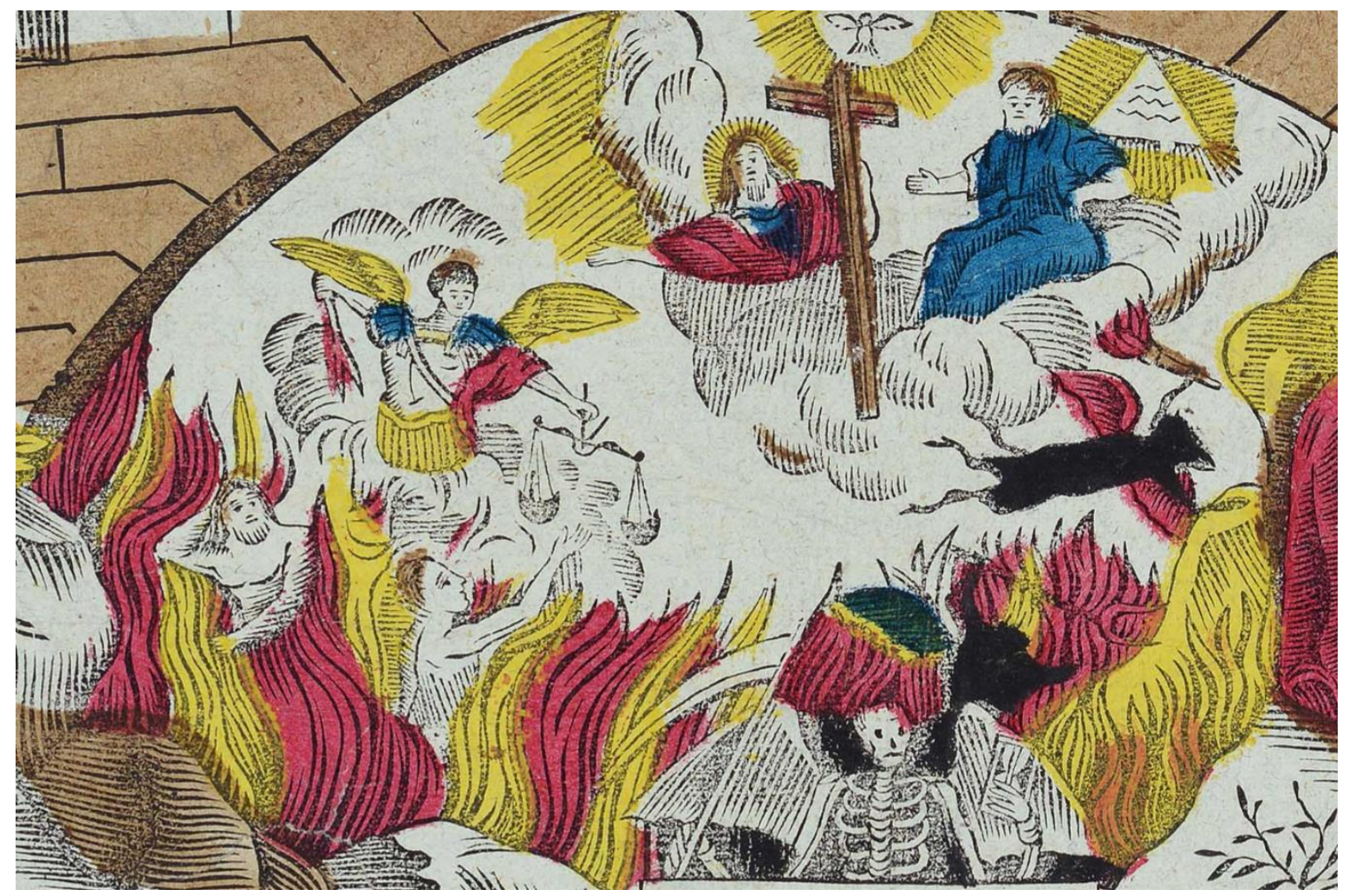

Fonte: Musée de I’Image Ville d'Épinal número de acervo 2010.5.6841 B, negativo fotográfico de H. Rouyer.

A segunda personagem (figura 11), nessa parte do motivo, representada de forma clássica como um esqueleto com uma foice, é a própria morte, embora as asas sejam um elemento incomum em sua iconografia.

\footnotetext{
${ }^{22}$ Morgan parte da obra de Henry Hubert Marcel Mauss (1964 [inglês], 2016 [francês]), primeira edição 1898 em francês.
} 
Na mão direita, ele segura uma lança com uma bandeira totalmente vermelha; na esquerda, uma ampulheta ou um relógio de areia. Reparamos que esse motivo, sem a ampulheta, já aparece na xilogravura de Jörg Breu, entretanto, ainda integrado à narrativa visual da escada da vida, não do julgamento final ou universal. Já em nosso caso, a morte é integrada ao discurso religioso.

Concluímos que a narrativa religiosa não articula uma vulnerabilidade da divindade - no sentido de uma compaixão - se não for de forma muito pontual pela mão estendida de Cristo. Todos os outros indicadores são afirmações da inevitabilidade da morte e da posterior cobrança (balança) dentro de um sistema de economia do sagrado de negociação de boas obras, inclusive um sistema post-mortem de redução de dívidas, ou do tempo de permanência no purgatório, pela compra de indulgências pelos parentes ainda vivos. A vulnerabilidade humana, em termos religiosos, representada pelas pessoas fragilizadas e expostas às chamas, não representa um peso que pode ser transformado em desconto diante do rigor de uma balança. Seu sofrimento não é objeto de uma ação compassiva, mas de cálculo e de cobrança. A percepção e a articulação da vulnerabilidade, especialmente pelas cenas 1 e 11, ou das idades de 1 e 100 anos, também pelas cenas 6 a 9, ou das décadas 60 até 90, não encontram sua correspondência na narrativa visual religiosa.

\section{Considerações finais}

Fechamos então este pequeno ensaio com uma observação dupla quanto ao discurso visual em relação à vulnerabilidade e à importância das narrativas visuais para os estudos da religião e da educação.

Concluímos que a xilogravura articula a vulnerabilidade humana, tanto como sinaliza da fragilidade humana em diversas fases da vida, em especial na infância e na velhice, até se tornar, novamente, criança, no sentido de um ser humano em plena dependência de outros. Isso ocorre sem qualquer ridicularização desse estado na velhice, como ocorrera em xilogravuras com o mesmo motivo no século 16, dependentes de certas narrativas greco-romanas ou da Antiguidade. Entretanto, a vulnerabilidade como elemento da condição humana comum a todas as fases da vida e que requer a solidariedade humana em todas fases da vida, ainda, não é articulada. Aparece "nas pontas do ciclo da vida” o tom de respeito para com essa condição humana universal, 
encontrada no início e no fim da vida, mas, ainda não, para a longa fase de declínio das capacidades físicas e faculdades racionais. Educa também para uma aceitação da vulnerabilidade como condição humana universal, o que contribuiria, em muito, para chamar a vulnerabilidade como um aspecto essencialmente humano, até que a humanidade e vulnerabilidade se fundem. Assim, a narrativa visual se distancia parcialmente das teorias educacionais da época a respeito da deficiência, mas, confirma as teorias teológicas da mesma época.

Na educação, a compreensão social dos impedimentos de pessoas com deficiência - cumprindo o ciclo biológico, todos nascem e morrem como pessoas com grandes incapacidades - é da segunda parte do século 20. Segundo a teoria, nos séculos 17 e 18 reina ainda a compreensão mítica - uma incapacidade é resultado de uma punição divina ou da pessoa mesma ou de gerações anteriores - para se chegar depois à compreensão clínica - incapacidades são anomalias biológicas que devem ser, o quanto antes e o máximo possível, corrigidas.

Fica evidente também que o discurso religioso da xilogravura, primeiro, apesar de representar, ainda, um discurso punitivo mediante a cobrança de boas obras, não articula mais a ideia que a própria vulnerabilidade seja resultado de um desvio, de uma transgressão ou, teologicamente falando, do cometimento de pecados. Apesar de a palavra "consolo" aparecer uma vez na subscriptio ao seu final, a narrativa religiosa também não articula uma vulnerabilidade divina em que a vulnerabilidade humana pode se espalhar e fazer as pazes com essa condição.

Não parece ser por acaso que, nessa xilogravura, a narrativa religiosa fica mais separada da narrativa educativa. Ela não acompanha mais o discurso educacional ou a experiência humana, está entranhada num tipo de auto alienação. Somente no século 20 o tema da vulnerabilidade terá seu reencontro com as narrativas religiosas, antecipadas, a partir dos meados do século 19, por novas interpretações da morte do salvador como sinal de uma vulnerabilidade solidária.

Afirmamos que a xilogravura estudada não somente pode ser lida sob perspectivas diferentes, mas, ela mesma acaba articulando, parcialmente, olhares diferentes sobre o ser humano. Vimos que estes dois olhares são sinalizados pela duplicidade de títulos e a superação visual entre um discurso educacional e um discurso religioso. No 
momento em que investigamos estes dois discursos na perspectiva da vulnerabilidade, iniciamos um diálogo do significado e lugar desse conceito na educação e nas ciências da religião. Percebemos que, nas duas áreas, o conceito chegou com força somente no século 20, com primeiros sinais de consideração no século 19 e que, nas duas áreas de conhecimento, ele acaba sendo um elemento-chave para seu futuro desenvolvimento.

\section{REFERÊNCIAS}

ADAM, Júlio César. Pregando vulnerabilidade: a teologia da libertação, a ética do cuidado e a pregação no contexto brasileiro e latino-americano. Estudos Teológicos, São Leopoldo, v. 54, n. 2, p. 350-362, jul./dez. 2014.

AMARAL, Lígia Assumpção. Conhecendo a deficiência (em companhia de Hércules). São Paulo: Robe Editorial, 1995.

ARENDT, Hanna. Entre o passado e o futuro. São Paulo: Perspectiva, 2009.

ARISTÓTELES. Política. Rio de Janeiro: Hemus, 1966.

ASSMANN, Hugo; SUNG, Jung Mo. Competência e sensibilidade solidária: educar para a esperança. Petrópolis: Vozes, 2000.

BACH, Ulrich. Ohne die Schwächsten ist die Kirche nicht ganz. Bausteine einer Theologie nach Hadamar, Neukirchen-Vluyn 2006. [Tradução do título principal: Sem os mais frágeis, a igreja não é integral: elementos de uma teologia depois de Hadamar $\left.{ }^{23}\right]$.

BACH, Ulrich: Dem Traum entsagen, mehr als ein Mensch zu sein. Auf dem Wege zu einer diakonischen Kirche, Neukirchen-Vluyn, 1986. [Tradução do título principal: Desistir do sonho, ser mais do que um ser humano: no caminho para ser uma igreja de diaconia].

BACH, Ulrich: Kraft in leeren Händen. Die Bibel als Kursbuch, Freiburg-Basel-Wien 1983. [Tradução do título: Força em mãos vazias: a bíblia como livro-guia].

BACH, Ulrich: Volmarsteiner Rasiertexte. Notizen eines Rollstuhl-Fahrers, Gladbeck/Westfalen [1979]. [Tradução do título: Textos para pensar direto de Vollmar: Notícias de um cadeirante].

BACH, Ulrich: Wie lange noch wollen wir fliehen? Einspruch gegen die unheilvolle These vom Heilungs-Auftrag. Diakonie, v. 19, p. 390-397, 1993. [Tradução do título do artigo: Quanto tempo queremos ainda fugir? Proteste contra a tese desastrosa da "vocação de curar"].

\footnotetext{
${ }^{23}$ Hadamar era um hospital alemão para pessoas com uma deficiência que participou no programa de eutanásia nacional socialista. O título remete ao movimento de uma "teologia depois de Auschwitz".
} 
BIELER, Andrea. Verletzliches Leben: Horizonte einer Theologie der Seelsorge. Göttingen: Vandenhoeck \& Ruprecht, 2017. [Tradução do título principal: Vida vulnerável: horizontes de uma teologia pastoral].

BISOL, Claudia; PEGORINI, Nicole; VALENTINI, Carla. Pensar a deficiência a partir dos modelos médico, social e pós-social. Cadernos de Pesquisa, São Luís, v. 24, n. 1, jan./abr. 2017.

BOESAK, Allan Aubrey. Dare we speak of hope? Searching for a language of life in faith and politics. Grand Rapids: Eerdmans, 2014.

BUNTON, John. Meditations on the several ages of man's life, representing, the vanity of it, from his cradle to his grave. Adorned with proper Emblems to which is added scriptural poems. Londres: impresso por F. Blare, 1701.

BURROW, John Anthony. The ages of man: A study in medieval writing and thought. Oxford: Clarendon, and New York: Oxford University Press, 1986.

CMI. Uma igreja de todos e para todos: uma declaração teológica provisória. CMI. São Paulo: ASTE, 2005.

CULP, Kristine A. Vulnerability and glory: a theological account. Louisville, KY: Westminster John Knox Press, 2010.

DENTZ, Rene, FERREIRA, Vicente de Paula. Corpo e vulnerabilidade: caminhos da teologia pós-moderna. Interações, v. 12, n. 1, p. 45-59, jan./jun. 2017.

DOVE, Mary, The perfect age of man's life. Cambridge: Cambridge University Press, 1986.

EHMER, Josef. Lebenstreppe. In: Enzyklopädie der Neuzeit, vol. 9. Stuttgart: J.B. Metzler'sche Verlagsbuchhandlung und Carl Ernst Poeschel Verlag, 2009. col. 50-55. [Tradução do título: Escada da vida]

EHMER, Josef. Lebenslauf [in historischer Persepktive]. In: Enzyklopädie der Neuzeit, vol. 7 [Konzert- até Männlichkeit], Stuttgart: J.B. Metzler'sche Verlagsbuchhandlung und Carl Ernst Poeschel Verlag, 2008. col. 677-699. [Tradução do título do artigo: O caminho da vida em perspectiva histórica].

GANDOLFO, Elizabeth O'Donnell. The power and vulnerability of love: a theological anthropology. Minneapolis, MN: Fortress, 2015.

GIRARD, René. A violência e o sagrado. São Paulo: Paz e Terra, 1990.

GNILKA, Christian. Aetas spiritalis: die Überwindung der natürlichen Altersstufen als Ideal frühchristlichen Lebens. Cologne e Bonn: Peter Hanstein Verlag, 1972. [Coletânea Theophaneia - Beiträge zur Religions- und Kirchengeschichte des Altertums, vol. 24]. [Tradução do título: Idades espirituais: da superação das idades naturais como ideal da vida no início do cristianismo].

HABER, Carole; JOHNSON, Paul; THANE, Pat (ed.). Old age from antiquity to postmodernity. New York: Routledge, 1998. 
HUBERT, Henri; MAUSS, Marcel. Essai sur la nature et la fonction du sacrifice. Paris: PUF: Quadrige, 2016. [Tradução do título: Ensaios sobre a natureza e a função do sacrífico].

HUBERT, Henri; MAUSS, Marcel. Sacrifice: its nature and functions. Edição reimpressa e revisada. Chicago: University of Chicago Press, 1964.

METZLER, Irina. A social history of disability in the middle ages: cultural considerations of physical impairment. New York: Routledge, 2013. [Coletânia: Routledge Studies in Cultural History].

MINOIS, Georges. History of old age: from Antiquity to the Renaissance. Tradução de Sarah Hanbury Tenison. Chicago: University of Chicago Press, 1989.

MOLTMANN, Jürgen. Diaconia en el horizonte del Reino de Dios: hacia el diaconado de todos los creyentes. Tradução de Constantino Ruiz Garrido. Guevara: Sal Terrae, 1987.

MORIN, Edgar. O método V: a humanidade da humanidade - a identidade humana, Tradução de Juremir Machado da Silva. Porto Alegre: Sulina, 2003.

OLIVEIRA, Ivanilde Apoluceno. Saberes, imaginários e representações na educação especial: a problemática ética da 'diferença' e da exclusão social. Petrópolis: Vozes, 2004.

PLATÃO. La República, o de la justicia. In: Obras completas. Madrid: Aguilar, 1972. p. $655-844$.

RAMINELLI, Ronald. Eva Tupinambá. In: PRIORE, Mary del (org.). História de mulheres no Brasil. São Paulo: Contexto, 2011. p. 11-43.

RITSCHL, Benjamin Albrecht. Die christliche Lehre von der Rechtfertigung und Versöhnung: Die Geschichte der Lehre. Bonn: Editora Marcus, 1900. v. 1. [Tradução do título principal: O ensino cristão da justificação e redenção: a história da doutrina].

RITSCHL, Benjamin Albrecht. Die Entstehung der altkatholischen Kirche. Bonn: Adolph Marcus, 1850. [Tradução do título principal: O surgimento da Igreja Católica Antiga].

SÁ, Nídia. Cultura, poder e educação de surdos. Manaus: Editora da Universidade Federal de Manaus, 2002.

SCHOFER, Jonathan Wyn. Confronting vulnerability: the body and the Divine in Rabbinic Ethics. Chicago: University of Chicago Press, 2010.

SCHÖNE, Anja. Lebenszeiten des Menschen. In: BREDNISCH, Rolf Wilhelm (ed.). Enzyklopedia der Märchen: Handwörterbuch zur historischen und vergleichenden Erzählforschung. Berlin e New York: Walter de Gruyter, 1996. vol 8 [Klerus - Maggio], p. 882-846. [Tradução do título do verbete: Tempos de vida do ser humano]. 
SKLIAR, Carlos. (org.) Educação e exclusão: abordagens sócio-antropológicas em educação especial. Porto alegre: Mediação, 1997. (Cadernos de autoria).

SÖLLE, Dorothee. Sofrimento. Tradução de Antonio Estevao Allgayer. Petrópolis, RJ: Vozes, 1996.

STALSETT, Sturla. Vulnerabilidad, dignidad y justicia: valores éticos fundamentales en un mundo globalizado. Revista Venezolana de Gerencia, Maracaibo, Zula, Venezuela, v. 9, n. 25, p. 1-15, jan. 2019. Disponível em: http://dx.doi.org/10.3796o/revista.v9i25.9723. Acesso em: 10 de nov. 2019.

THIISSEN, Jo; OVERDICK, Michael. Die Lebenstreppe und ihre Verwandten. In: VANJA, Konrad et al. (ed.). Arbeitskreis Bild Druck Papier: Tagungsband Berlin 2012. Münster: Waxmann, 2013. p. 41-66. [Tradução do título do capítulo: A escada da vida e seus motivos semelhantes].

TROYANSKY, David G. Balancing social and cultural approaches to the history of old age and aging in Europe: a review and an example form post-revolutionary France. In: JOHNSON, Paul; THANE, Pat. Old age from Antiquity to Post-Modernity. London:

Routledge, 1998. p. 96-109. 